\title{
Development of palm oil-cattle integration program to support self-sufficiency of beef and development of human resources
}

\author{
Djatmiko Pinardi ${ }^{* 1)}$, Daru Mulyono ${ }^{1)}$, Dimar Sari Wahyuni ${ }^{1)}$, and Maman Surachman ${ }^{1)}$ \\ ${ }^{1)}$ Center for Agricultural Production Technology The Agency for the Assessment and \\ Application of Technology \\ Laptiab 610 Building, Puspiptek, Serpong, Tangerang Selatan 15315, Indonesia
}

Submitted: 30 May 2019, Accepted: 23 January 2020

\begin{abstract}
The research aims to provide input (suggestions) to the government especially in the development of the Palm Oil-Cattle Integration Program (PCIP) to increase beef production and human resources development. This research is analytical descriptive research with information and primary data was gathered through various methods such as audience with key informants and focus group discussion. Secondary data was gathered through scientific publication review. Data analysis was conducted to predict both national beef production and consumption by using a trend-damped exponential forecasting model. The result of the research shows that national beef production 2018-2045 is projected to increase with an annual average growth rate of $1.19 \%$, while national beef consumption increase with an annual average growth rate of $2.34 \%$. The development of beef cattle through PCIP is prospective. The major problems faced by cattle ranchers today are the lack of livestock grazing and limited livestock feed. PCIP offers the solution to fulfill the need for cattle from the potential biomass which can be used as feed materials which is available throughout the year regardless of the season. Moreover, several types of weeds that contain high nutrients and resistant to shade which potential for Cattles feed materials could be planted under the oil palm plantation. It is estimated that by 2034 the gradual development of PCIP reaches up to $2,150,000 \mathrm{ha}$, Indonesia will be able to achieve national beef self-sufficiency and expected will impact to increasing quality of human resources.
\end{abstract}

Keywords: palm-cattle integration; self-sufficiency; human resources development

\footnotetext{
*Corresponding author: djatmikopinardi@gmail.com
} 


\section{INTRODUCTION}

The Government of Indonesia through the Ministry of Agriculture strives to fulfill the consumption of beef to fulfill the nutritional needs of the community. Based on the Law No. 18/2012 on Food stated that the government of Indonesia is obliged to increase the fulfillment of both the quantity and the quality of food to improve the quality of human resources. Related to the fulfillment of food consumption, the International Food Policy Research Institute (IFPRI) uses the Global Hunger Index (GHI) indicator to measure and track hunger in a country.

The GHI does not only reflect the proportion of malnutrition population especially in children who are susceptible to food, protein, or micronutrient deficiencies (essential vitamins and minerals) leads to high risk of disease, but also includes poor physical and cognitive development, or death. Based on the GHI score in 2016, Indonesia was included in the category of Serious Hunger. Compared to other ASEAN countries, food conditions in Indonesia were lower than the Philippines, Thailand, and Vietnam in the level of Medium Hunger. Malaysia has achieved a much better food condition with Low Hunger. In 1992, Indonesia had a score of 35.8 or categorised as "Worrying Hunger".

With the continuous improvement of food, Indonesia has a score changed to 21.9 or became "Serious Hunger Level" in 2016. Furthermore, according to the report of the Ministry of Health (2018), the stunting rate in Indonesia in 2017 was still relatively high up to $29.5 \%$. Stunting occurred is due to a lack of nutrition. Concerning food conditions, especially nutrients derived from beef indicated that the national beef production was not able to meet the needs of public consumption. In 2017 the Association of Indonesian Beef Cattle Businesses predicted that beef consumption will reach an average of 2.75 $\mathrm{kg} / \mathrm{capita} /$ year.
With a population of 261.9 million in Indonesia, the need for beef was up to 720,225 tons, while production was only about 437,300 tons. Therefore, the government had to import Cattles and beef up to $39.3 \%$ of national beef needs (Gapuspindo, 2017). The increasing number of population in Indonesia and the increase of public awareness on the importance of animal protein increased the consumption of meat, especially beef. Directorate General of Livestock and Animal Health, Ministry of Agriculture stated that beef consumption per capita in 2015 increased by $60.0 \%$ compared to the year before (Ministry of Agriculture, 2016). The increase rate of beef demand was not followed by an increased rate of beef production.

This was causing the deficiency of national beef. Therefore, the government continues to importing Cattles and beef up to the present time. Data in 2013 showed that beef and beef imports were up to $35 \%$ of national beef requirements (Atmakusuma, Harmini, and Winandi, 2014). The Indonesian government is currently paying attention to the adequacy of meat consumption as a source of animal protein, especially beef. In 2004, the Government established a policy concerning beef self-sufficiency targets to be achieved in 2011 .

However, the policy was postponed in 2014 because it failed to achieve the target. At the moment, the government continues to strive to accelerate the target of fulfilling the beef cattle population in a sustainable manner as described in Minister of Agriculture Regulation No. 48 / Permentan / PK.210 / 10/2016. The increasing deficit between the production and consumption of beef in Indonesia is caused by several problems, such as the lack of cattle grazing fields.

Therefore, one of the efforts to develop Cattle ranchers in Indonesia is through the development of the Palm OilCattle Integration Program (PCIP) where 
palm oil estate is used as the Cattles grazing field. In 2016 there were 11.20 million ha of oil palm plantations in Indonesia as potential cattle grazing fields. In the cultivation of palm oil obtained side product form of palm midrib, palm leaves, palm oil waste such as palm cake and solid decanter where it can be utilised as a highquality Cattles feed material, cheap, and easy to be done by Cattle ranchers. Besides that, under the palm plantation can be developed several types of weeds that contain high nutrients and resistant to shade which potential for Cattles feed. The government's efforts to increase the production of beef because in general, the quality of animal protein, especially derived from beef is better than the protein derived from vegetables.

This is because the quality of protein derived from beef contains more amino acids, complete minerals, iron richest and more easily absorbed by the body than the iron in vegetables or processed foods (Fitri, 2012). Thus the protein derived from beef has a very important role to build intellectual life of the nation and improve public health. Along with the increasing population in Indonesia and increasing public awareness of the importance of animal protein causes the consumption of beef continues to increase which results in the demand for beef is much larger than the production. This condition needs to be addressed by the government. Moreover, the fulfillment of national beef requirements will improve the quality of human resources.

Although many studies have been conducted on the integration of palm oil, no research analysed the formulation and estimation for projections of beef production and consumption related to government policy (Ministry of Agriculture) regarding the development of cattle-oil palm integration programs. Therefore the research aims to provide suggestions to the government in the development of PCIP as an effort to meet the needs of national beef consumption.

\section{MATERIALS AND METHOD}

This study is an analytical descriptive study with the technique of collecting information on primary and secondary data was done through various methods namely: (a) Interviewing key informants from the Ministry of Agriculture (Directorate General of Animal Husbandry and Animal Health), Animal Research Center, Food Security Agency, Higher Education (Faculty of Animal Husbandry, Bogor Agricultural Institute (IPB), Faculty of Veterinary Medicine, IPB, Department of Nutrition Faculty of Human Ecology, IPB), as well as private institutions that deal with or related to livestock such as: Association of Cattle Farming Businesses (Gapuspindo) and Indonesian Palm Oil Business Association (GAPKI), (b) yang mana???? (c) Review of policy documents issued by both central and local governments related to livestock development.

A Focus Group Discussion (FGD) with some experts from Research Institutes, Universities, and other relevant stakeholders or stakeholders was done to support data and information. Data analysis was conducted to predict both the production side and the national beef consumption. The method of analyzing cattle population projection data is based on time series data for 2017-2045. The method used is ARIMA which is one of the forecasting methods based on time series data. ARIMA is a combination of Autoregressive (p) and Moving Average (q) will form the ARIMA model (p, d, q) (Wei, W. 2006). The model used was ARIMA ( $p=1, d=1, q=2)$. This model was selected based on the test results in some tentative ARIMA models. One of some tentative ARIMA models was statistically significant for an accurate model of forecasting

Population projection to project total beef consumption using the National Development Planning Agency (Bappenas), Central Bureau of Statistics (BPS), and the United Nations Fund for Population Activities (UNFPA) projection for 2010- 
2035. The projected population for the period of 2035-2045 was adjusted to the growing trend of the previous year. The implementation of this assessment was supported by funding from the Budget Implementation of the Agency for the Assessment and Application of Technology (BPPT) in 2017.

\section{RESULTS AND DISCUSSION}

The low consumption of beef in Indonesia is due to the high price of beef in the market. The main factor causing the high price is the greater demand compared to the production. The Ministry of Agriculture stated that the growth of beef consumption during the period of 19992014 increased significantly by $4.29 \%$ with the average consumption of beef in Indonesia of $2.08 \mathrm{~kg} /$ capita/year (Ministry of Agriculture, 2015). Furthermore, it was predicted that the growth or trend of meat production from 2014-2024 will only reach $1.54 \%$, while the trend of beef consumption reaches $3.61 \%$ as shown in Table 1. This causes a larger imbalance between beef production and consumption in Indonesia.

Table 1. Projection of Beef Production and Consumption in Indonesia, 2014-2024

\begin{tabular}{ccccc}
\hline Year & \multicolumn{2}{c}{ Beef Production } & \multicolumn{2}{c}{ Beef Consumption } \\
\cline { 2 - 5 } & (ton) & Trend $(\%)$ & (ton) & Trend $(\%)$ \\
\hline 2014 & $435,086.19$ & & $593,516.62$ & \\
2015 & $507,631.61$ & 16.67 & $653,980.57$ & 10.19 \\
2016 & $441,763.03$ & -12.98 & $651,424.27$ & -0.39 \\
2017 & $452,231.45$ & 2.37 & $711,114.96$ & 9.16 \\
2018 & $479,463.87$ & 6.02 & $774,937.66$ & 8.98 \\
2019 & $490,558.29$ & 2.31 & $819,964.36$ & 5.81 \\
2020 & $501,652.71$ & 2.26 & $864,991.05$ & 5.49 \\
2021 & $512,747.13$ & 2.21 & $910,017.75$ & 5.21 \\
2022 & $523,841.55$ & 2.16 & $955,044.45$ & 4.95 \\
2023 & $534,935.97$ & 2.12 & $1,000,071.14$ & 4.71 \\
2024 & $546,030.39$ & 2.07 & $1,045,097.84$ & 4.50 \\
Average Growth Rate & 1.54 & & 3.61 \\
\hline
\end{tabular}

Source: Ministry of Agriculture (2016)

The government imported Cattles and beef to overcome this problem to meet the needs of beef consumption. However, it will not make this nation grow but it will threaten the stability of food security. Moreover, along with the increase of population and welfare of the community, the need for the type and quality of meat is also increasing and diverse.

National beef consumption and projection 2018-2045 will continue to increase with an average growth of $1.59 \%$ per year or grow from $2.67 \mathrm{~kg}$ per capita in 2018 to $4.23 \mathrm{~kg}$ per capita by 2045 . With the projection of consumption per capita and average population growth rate of $0.75 \%$, national beef consumption is projected to grow by an average of $2.34 \%$ from 745.519 tons in 2018 to 1.359 .019 tons in 2045. The result of the projection analysis of beef consumption 2018-2045 is shown in Figure 1.

While national production and projection of beef 2018-2045 tend to increase with an average growth rate of $1.19 \%$ per year. Similarly, national beef consumption from 2018-2045 is projected to increase with an average growth of $2.34 \%$. Beef consumption growth greater than production causes a deficit of beef which will increase until 2045. The national production balance and consumption of beef can be seen in Figure 2. 


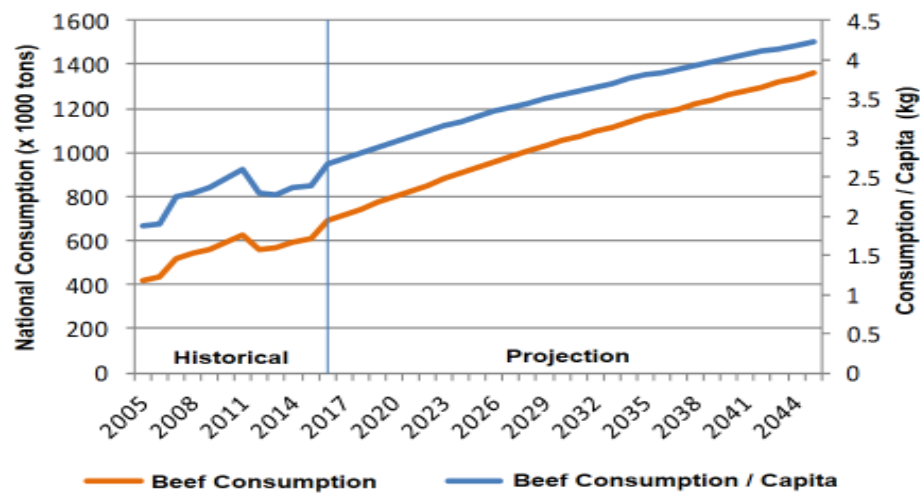

Figure 1. Projection of Beef Consumption and Beef Consumption per Capita, 2018-2045 Source: Analysis Results

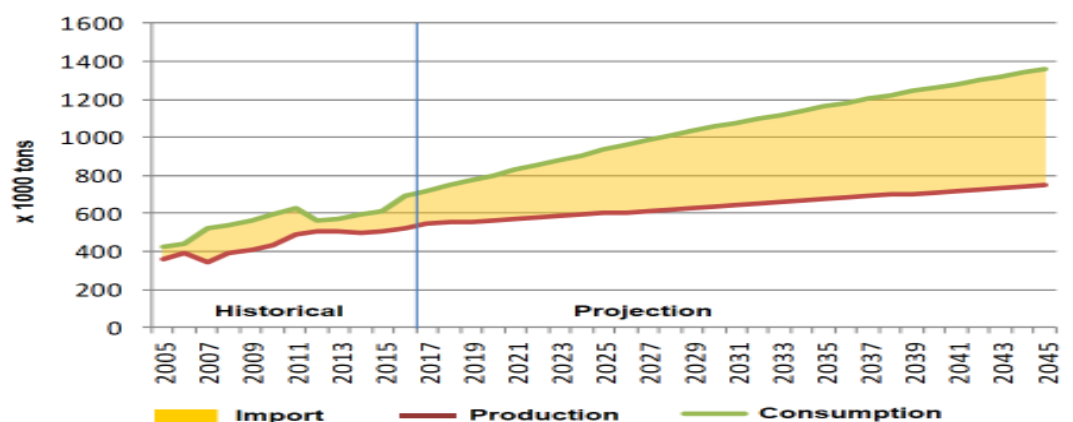

Figure 2. Balance of Beef Production and Consumption in Indonesia, 2018-2045 Source: Analysis Results

Figure 2 shows that by 2045 it is projected that national beef production will reach 749,290 tons while beef consumption has reached 1,359,019 tons. This means that in 2045 there will be a deficit of national beef supply reach to a high of 609,729 tons. Therefore, the Indonesian government should continue to work to reduce the deficit of beef that increased continuously. One strategy to reduce the deficit is to increase Cattle populations to increase beef production is through the development of Cattles ranching in PCIP.

\section{Development of Palm Oil-Cattle Integration Program (PCIP)}

The development of Cattles through PCIP could solve the lack of cattle grazing fields and limited livestock feed as the major problem in cattle farming. Animal feed is one of the factors that determine the success of the business which is the largest component in the Cattle business that reaches $60-80 \%$. The lack of availability of feed-in quantity and quality causes low beef production in Indonesia.

The PCIP is one of the government's real efforts where its implementation begins with the issuance of Regulation from the Minister of Agriculture no. 105/Permentan/ PD.300/8/2014 on the Integration of Oil Palm Plantation Business with Beef Cattle Business. This program was a follow-up to the development of the integration program of Cattle-palm as a national program as outlined in the Strategic Plan of the Ministry of Agriculture 2015-2019. There are 14.03 million hectares of oil palm plantations in 2017 as a potential source of animal feed for cattle grazing fields. Therefore, with the development of PCIP, the need for cattle feed will be fulfilled by the potential biomass which can be used as feed materials, such as boneless leaves, palm 
stem, empty bunches, fibers, palm mud (solid), palm kernel cake, and weed which grows under oil palm plantation. Besides that, the supreme of feed materials are available throughout the year regardless of the season. Biomass potential in oil palm plantations as Cattles feed material is presented in Table 2.

Table 2. Potential of Feed Materials from Biomass of Oil Palm Plantation

\begin{tabular}{ll}
\hline Biomass Side & $\begin{array}{l}\text { Potential Fodder } \\
\text { (ton DW/ ha/year) }\end{array}$ \\
\hline Products & 0.7 \\
Poneless Leaf & 5.2 \\
Empty Bunches & 3.4 \\
Fibres & 2.7 \\
Palm Mud (Solid) & 1.1 \\
Palm kernel cake & 0.5 \\
Total Biomass & 13.6 \\
\hline
\end{tabular}

Source: Mathius (2008)

DW $=$ Dry Weight

The use of cultivation of oil palm waste as animal feed materials should be processed trough fermentation or amoniasi to improve the quality of feed for increasing the nutrient value and fiber content coarse.

Complete feed for Cattles can be made from palm stem in fresh form or processed or cut grass plus concentrate. This concentrate is made from palm oil processing as byproducts: palm kernel cake and palm mud added with rice bran, cassava grout, and molasses. The results of the chemical analysis indicate that the quality of Complete Feed and Concentrate from waste or by-product of oil palm was almost meet the Indonesian National Standard (INS) of Beef Concentrate Feed (SNI 3148.2.2009) which described in Table 3.

Table 3. Chemical Composition of Concentrate and Complete Feed from Palm Waste

\begin{tabular}{lccc}
\hline Chemical Composition & $\begin{array}{c}\text { Concentrate } \\
(\% \text { DW })\end{array}$ & $\begin{array}{c}\text { Complete Feed } \\
(\% \text { DW })\end{array}$ & $\begin{array}{c}\text { Composition } \\
\text { According INS (\%) }\end{array}$ \\
\hline Crude Protein & 16.23 & 14.07 & $\geq 14$ \\
Ash & 8.41 & 8.03 & $\leq 12$ \\
Fat & 6.38 & 5.07 & $\leq 6$ \\
Fibre & 22.92 & 27.28 & $\leq 35$ \\
Total Digested Nutrient & 76.23 & 67.51 & $\geq 65$ \\
\hline
\end{tabular}

Source: Ministry of Agriculture (2016)

DW $=$ Dry Weight

Table 3 shows that the production of Complete Feed and Concentrates derived from palm products is almost entirely eligible for Cattles to feed except for fat content at concentrates which is only slightly higher than INS. However, this is not a problem because according to Wina and Susana, (2013) suggested that these slightly higher levels of fat can be overcome by adding calcium fatty acid.
The abundance of palm plantation in Indonesia can be used to produce calcium fatty acids. The adding of calcium fatty acid will cause the efficiency of feed, quality of carcass, reproduction, production, and quality of Cattle's milk is increasing. Furthermore, to improve the quality of palm waste containing high crude fiber as animal feed can be done with several treatments, namely: physical, 
chemical and biological. Physical treatment is done by chopping/cutting, soaking in water, and drying. Chemical treatment is carried out by using chemicals such as $\mathrm{NaOH}, \mathrm{Ca}(\mathrm{OH}) 2$, ammonium hydroxide, urea, sodium carbonate, sodium chloride, and others. While biological treatment is done by using bacteria and fungi (Mathius et al., 2008). Besides waste in palm plantations, PCIP could develop some weeds that can grow under palm crops as a source of forage, although not all plants are favored by livestock. For example, five types of weeds predominate in Immature Crops (IC) as well as in Producing Crops (PC) in palm plantations in Jambi reported Syahputra, Sarbino, and Dian (2011). Furthermore, there are two dominant weed species in palm plantations in Central Kalimantan that are the potential to feed cattle, namely Axonopus compressus and Paspalum conjugatum. Table 4 shows some species of weed that grows well under the shade of palm crops.

Table 4. Weed Species in Some Oil Palm Plantations in Indonesia

\begin{tabular}{cclll}
\hline Location & Oil Palm & Weed Species \\
& Condition & \\
\hline Jambi & Immature & Fimbristylis acuminate, Nephrolepis biserrata, Elaeis \\
& Crops (IC) & guinennsis, Cyperus compressus, Murdannia nudiflora \\
& Producing & Fimbristylis acuminate, Digitaria ciliaris, Nephrolepis \\
Central & Crops (PC) & biserrata, Davallia denticulate, Camponotus compressus \\
Kalimantan & Producing & Axonopus compressus, Paspalum conjugatum, Ageratum \\
& Crops (PC) & conyzoides, Nephrolepis biserrata, Clidermia hirsute, \\
& & Melastoma spp, Mikania micrantha, Borreria alata \\
(tumbuhan berdaun lebar)
\end{tabular}

Source: Purwantari, Tiesnamurti, and Adinata (2015)

According to Adriadi, Chairul, and Solfiyeni (2012) there are 20 families, 47 genera and 56 species of broadleaf and broadleaf weeds that grow well under palm crops in Sumatera, such as Asystasia intrusa, Crassocephalum crepidioides, Stachytarpeta indica, Mimosa invisa, Euphorbia heterophylla, Saccharum spontaneum, Ottochloa nodosa, Setaria barbata, Paspalum spp, Chrysopogon aciculatus, Cyperus rotundus, Panicum repens, and others. Axonopus compressus and Ottochloa nodosa are very resistant to shade and are favored by livestock including Cattles, so have great potential as a source of forage feed that can support the implementation of PCIP.

The nutrient content of some wellgrown weeds under palm crops, especially those containing many proteins, are Centrosema pubescens, Calopogonium mucunoides, Pueraria phaseoloides, and others can be seen in Table 5. Table 5 shows that for Cattles development it is necessary to introduce weeds containing high protein, phosphorus $(\mathrm{P})$, and calcium (Ca) to be developed under oil palm stands as quality livestock feeds, such as Centrosema pubescens, Calopogonium mucunoides, Pueraria phaseoloides. In the area of oil palm plantations the existence of a superior grass is expected to help meet the needs of forage feed both in terms of quality and quantity that is difficult to find in nature. King grass or Pennisetum purpureophoides is an excellent source of forage feed to meet the needs of animal feed.

This king grass can be developed especially in the palm plantation when the plant is still young or Immature Crops. According to Umiyasih and Anggreni (2003) that the plant source of forage feed can be used as animal feeds with production potential can reach as much as 3-5 tons/ha/year so it can support the development of Cattles optimally. In oldage oil palm or producing crops, the plant 
canopy closes so that the intensity of sunlight decreases. This condition resulted in the production of forage feed growing under palm plantation becomes less and less. Therefore, the strategy applied to produce crops in palm plantations is to develop weeds with high nutrient and shade resistant species in palm plantations, such as Fimbristylis acuminate, Digitaria ciliaris, Nephrolepis biserrata, Davallia denticulate, Camponotus compressus (Syahputra, Sarbino, and Dian, 2011). It can also be done by developing some leguminous plants around the palm plantation as forage feed such as Calopagonium, Centrocema, Mucuna, and Arachis. Forage feed derived from some types of leguminous can be used to improve the quality of animal feed which can be given in amounts up to $50 \%$.

Table 5. Proximate Analysis of Nutritional Content of Weed Species Which Grows under the Shading of Oil Palm Plantations

\begin{tabular}{lccccc}
\hline \multirow{2}{*}{ Weed Species } & $\begin{array}{c}\text { Dry } \\
\text { Material }\end{array}$ & $\begin{array}{c}\text { Raw } \\
\text { Protein }\end{array}$ & $\begin{array}{c}\text { Raw } \\
\text { Fat }\end{array}$ & $\begin{array}{c}\text { Phos- } \\
\text { phor }(\mathrm{P})\end{array}$ & $\begin{array}{c}\text { Calsium } \\
(\mathrm{Ca})\end{array}$ \\
\cline { 2 - 6 } & \multicolumn{5}{c}{$(\%)$} \\
\hline Axonopus compresus & 29.26 & 7.5 & 30.8 & 0.05 & 0.39 \\
Brachiaria mutica & 27.50 & 6.3 & 32.4 & 0.08 & 0.14 \\
Imperata cylindrica & 36.50 & 11.7 & 32.0 & 0.10 & 0.20 \\
Ischaemum muticum & 35.00 & 14.9 & 27.7 & 0.07 & 0.30 \\
Paspalum conjugatum & 21.70 & 11.0 & 28.6 & 0.09 & 0.31 \\
Mikania cordata & nd & 9.6 & 17.6 & 22.90 & nd \\
Calopogonium mucunoides & nd & 23.0 & 20.1 & 24.80 & nd \\
Centrosema pubescens & nd & 24.3 & 22.2 & 30.90 & nd \\
Pueraria phaseoloides & nd & 19.1 & 19.9 & 28.80 & nd \\
\hline Source Purwarides
\end{tabular}

Source: Purwantari, Tiesnamurti, and Adinata (2015)

nd $=$ no data

\section{Potential of Beef Production in PCIP}

The area of palm plantation in Indonesia increased in line with the market Crude Palm Oil (CPO) and its derivative products are growing. The implementation of PCIP is done by exploiting the potential of land for grazing fields and the production of biomass is very hudge and potential for the development of Cattles. In 2016 there were 11.20 million ha of palm plantations in Indonesia consisting of Smallholders $=4.74$ million ha, Large State Plantations $=0.71$ million ha and Private Large Plantations $=5.75$ million ha (Ministry of Agriculture, 2017).

In the Grand Design Ministry of Agriculture stated that to support the beef self-sufficiency program, the government has proclaimed an area of 1.5 million ha of palm plantations for the implementation of PCIP. Taking into account the production of biomass produced in the form of leaves as much as $360 \mathrm{~kg} / \mathrm{ha} / \mathrm{month}$ and each Cattle consumes as much as $240 \mathrm{~kg} /$ month then it is estimated that for two hectares of oil palm plantation can provide sustainable cattle feed for three Cattles.

With the calculation, the commencing of the PCIP program from 2007 to 2018 the area of palm plantation that has been used for the implementation of the PCIP is 150,000 ha and every year, there is an additional area for Cattles grazing area of 125,000 ha. It is assumed that every two hectares of oil palm plantations are used to shepherd three Cattles. For the fast-growing Cattles are such as Brahman Cross that can achieve an optimal weight of $400 \mathrm{~kg} / \mathrm{head}$ and a fattening period takes 1 year, Indonesia will be able to reduce the deficit of beef to zero or will achieve selfsufficiency of beef in 2034. On the other hand, with no PCIP, the increase of beef deficit in Indonesia in 2045 will up to 
609,729 tons. After reaching the national self-sufficiency of beef, the government needs to increase the area of palm plantations for the implementation of the PCIP for an average of 54,500 ha will be able to maintain the self-sufficiency of beef in a sustainable. The implementation of the PCIP in Indonesia until 2045 requires 2.7 million ha or less than a quarter of the national palm plantation, with cattle population up to $4,065,000$ which can be maintained easily, cheaply and efficiently.

Government efforts to increase beef production are very important because in general the quality of animal protein, especially that derived from beef is better than the protein derived from vegetables (Almatsier, 2013). Beef consumption contributes to the fulfillment of some essential nutrients, such as essential amino acids, vitamins (including B12) and complete minerals including iron and zinc (Wolk, 2017). Furthermore, Alonso, Colmenero, and Muniz, (2013) stated that the consumption of animal protein can improve health and reduce the risk of chronic diseases. Protein derived from beef has a very important role to increase the intelligence of the brain because it is the richest source of iron and more easily absorbed by the body compared with iron in vegetables or processed foods (Fitri, 2012).

\section{CONCLUSION}

The results of projection analysis indicated that national beef production will reach 749,290 tons and beef consumption only reaches $1,359,019$ tons in 2045 . This means that the national beef supply will be deficit up to 609,729 tons. The national beef supply deficit will continue to increase due to low beef production in Indonesia. Therefore, the government must continue to increase beef production to meet national consumption needs. PCIP is a strategy to develop cattle farming through the development. Through PCIP, the need for animal feed will be met by the potential of biomass that can be used as animal feed ingredients in oil palm plantations. In addition, under oil palm plantations, we can develop several types of weeds that contain high nutrition and shade tolerance as potential cattle feed.

In the analysis of the calculation, it is assumed that every two hectares of oil palm plantations are used for pasturing three heads of cattle. It is estimated that with the PCIP policy of 125 thousand hectares, development of PCIP will gradually reach a high of 2,125,000 ha in 2034 and Indonesia is expected to be able to achieve national meat self-sufficiency. It is expected that with the fulfillment of national beef consumption will improve the quality of human resources as well as increase national productivity and nation competitiveness.

\section{ACKNOWLEDGMENT}

The authors thank many colleagues from the Agency for Assessment and Application of Technology who have collaborated and assisted in the collection of data and information.

\section{REFERENCES}

Adriadi, A., Chairul, \& Solfiyeni. (2012). Analisis vegetasi gulma pada perkebunan kelapa sawit (Elais quineensis jacq.) di Kilangan, Muaro Bulian, Batang Hari. Jurnal Biologi UNAND, 1(2), 108-115. https://doi. org/10.25077/JBIOUA.1.2.\%P.2012

Almatsier, S. (2013). Prinsip Dasar Ilmu Gizi. Jakarta: Gramedia.

Atmakusuma, J., Harmini, \& Winandi, R. (2015). Mungkinkah swasembada daging terwujud ?. Risalah Kebijakan Pertanian Dan Lingkungan: Rumusan Kajian Strategis Bidang Pertanian Dan Lingkungan, 1(2), 109. https://doi.org/10.20957/jkebijak an.v1i2.10301

Fitri, D. (2012). Kosumsi daging sapi tingkatkan kecerdasan anak. Jurnal Aplikasi Teknologi Pangan, 1(1), 1-2.

Gapuspindo. (2017). Materi Audiensi Tim Badan Pengkajian dan Penerapan 
Teknologi dengan Direktur Eksekutif Gapuspindo. Jakarta.

Kementerian Kesehatan. (2018). 17,8\% Balita Indonesia Kekurangan Gizi.

Kementerian Pertanian. (2013). Model Pengembangan Sistem Integrasi Tanaman-Sapi Berbasis Inovasi.

Kementerian Pertanian. (2016). Peraturan Menteri Pertanian Nomor: 48/Permentan $\quad / P K .210 / 10 / 2016$ tentang Upaya Khusus Percepatan Peningkatan Populasi Sapi dan Kerbau Bunting. Jakarta.

Kementerian Pertanian. (2016). Roadmap Pengembangan Komoditas Sapi Potong/Kerbau 2016-2045. Bahan Raker Badan Peneltian dan Pengembangan Pertanian, Pusat Penelitian dan Pengembangan Peternakan.

Kementerian Pertanian. (2017). Statistik Perkebunan Indonesia 2015-2017. Kelapa Sawit.

Kementerian Sekretariat Negara Republik Indonesia. (2012). Undang-undang Republik Indonesia Nomor 18 Tahun 2012 tentang Pangan.

Mathius, I. (2008). Pengembangan sapi potong berbasis industri kelapa sawit. Pengembangan Inovasi Pertanian. Jurnal Penelitian Dan Pengembangan Pertanian, 1(1), 206-224.

Mathius, I., Sitompul, D., \& Manurung, B. (2008). Produk Samping Tanaman Dan Pengolahan Buah Kelapa Sawit Sebagai Bahan Dasar Pakan Komplit Untuk Sapi: Suatu Tinjauan. In Lokakarya Nasional Sistem Integrasi Kelapa Sawit-Sapi (pp. 120-128).

Olmedilla-Alonso, B., Jiménez-Colmenero, F., \& Sánchez-Muniz, F. J. (2013). Development and assessment of healthy properties of meat and meat products designed as functional foods. Meat Science, 95(4), 919-930. https://doi.org/10.1016/j.meatsci.201 3.03 .030
Purwantari, N., Tiesnamurti, B., \& Adinata, Y. (2015). Ketersediaan sumber hijauan di bawah perkebunan kelapa sawit untuk penggembalaan sapi. Wartazoa, 25(1), 47-54.

Standar Nasional Indonesia. (2009). Pakan Konsentrat Sapi Potong.

Syahputra, E., Sarbino., \& Dian, S. (2012). Weeds assessment di perkebunan kelapa sawit lahan gambut. Perkebunan Dan Lahan Tropika, 1(1), 37-42. https://doi.org/ 10.26418/PLT.V1I1.120

The International Food Policy Research Institute. (2017). Global Hunger Index.

Umiyasih, U., \& Anggreni, Y. (2003). Keterpaduan Sistem Usaha Perkebunan dengan Ternak, Tinjauan Tentang Ketersedian Pakan Hijauan Pakan untuk Sapi Potong di Kawasan Perkebunan Kelapa Sawit. In Lokakarya Sistem Integrasi Kelapa Sawit-Sapi (pp. 156-166).

Wei, W. (2006). Time Series Analysis: Univariate and Multivariate Methods (2nd ed.). USA: Pearson Education, Inc.

Wina, E., \& Susana, I. W. (2013). Manfaat lemak terproteksi untuk meningkatkan produksi dan reproduksi ternak ruminansia-review. Wartazoa, 23, 176-184.

Wolk, A. (2017). Potential health hazards of eating red meat. Journal of Internal Medicine, 281(2), 106-122. https://doi.org/10.1111/joim.12543 